\title{
Ketamine isomers suppress superantigen-induced proinflammatory cytokine production in human whole blood
}

[Les isomères de la kétamine suppriment la production de cytokine pro-inflammatoire induite par des superantigènes dans le sang complet humain]

Chika Kawasaki MD, Takashi Kawasaki MD, Masanori Ogata MD, Koichiroh Nandate MD, Akio Shigematsu MD

Purpose: To investigate the efficacy of S(+)-ketamine and R(-)-ketamine on staphylococcal enterotoxin B (SEB)-induced tumour necrosis factor (TNF)-, interleukin (IL)-6, and IL-8 production in human whole blood in vitro.

Methods: After Ethics Committee approval and informed consent, blood samples were obtained from ten healthy volunteers and diluted with five volumes of RPMI 1640. After adding different doses of ketamine isomers $(0-1000 \mu \mathrm{M})$, the blood was stimulated with SEB $\left(10 \mathrm{ng} \cdot \mathrm{mL}^{-1}\right)$. After a six-hour incubation period, the plasma TNF- activity was determined by the $\mathrm{L} 929$ cell cytotoxic assay and IL-6 and IL-8 concentrations were measured using an enzyme-linked immunoassay.

Results: Ketamine isomers significantly suppressed SEB-induced TNF- production at concentrations exceeding $50 \mu \mathrm{M}$. Ketamine isomers at concentrations exceeding $100 \mu \mathrm{M}$ also significantly suppressed SEB-induced IL-6 production. Furthermore, ketamine isomers at concentrations exceeding $500 \mu \mathrm{M}$ significantly suppressed SEB-induced IL-8 production. There were no significant differences between the suppressive effects of $\mathrm{S}(+)$-ketamine and $\mathrm{R}(-)$-ketamine on SEB-induced proinflammatory cytokine production.

Conclusion: This study demonstrated that ketamine isomers suppressed SEB-induced TNF-, IL-6, and IL-8 production in human whole blood.

Objectif : Vérifier l'efficacité de la S(+)-kétamine et de la R(-)-kétamine sur la production du facteur nécrosant des tumeurs (FNT)-a, de l'interleukine (IL)-6 et de l'IL-8, induits par l'entérotoxine B d'origine staphylococcique (EBS), dans le sang complet humain in vitro.
Méthode : Après avoir obtenu l'approbation du Comité d'éthique et le consentement éclairé des participants, nous avons recueilli des échantillons sanguins chez dix volontaires en santé et les avons dilué dans cinq volumes de RPMI 1640. Après l'addition de différentes doses d'isomères de kétamine (0-1000 $\mu \mathrm{M})$, le sang a été stimulé avec l'EBS ( $10 \mathrm{ng} \cdot \mathrm{mL}^{-1}$ ). À la suite d'une incubation de six heures, l'activité plasmatique de TNF-a a été déterminée par le dosage de la cytotoxicité cellulaire L929, et les concentrations d'IL-6 et d'IL-8 ont été mesurées au moyen d'un dosage immuno-enzymatique.

Résultats : Les isomères de kétamine ont supprimé de façon significative la production du TNF-a induit par l'EBS à des concentrations dépassant $50 \mu \mathrm{M}$, la production d'L-6 induite par l'EBS à des concentrations au delà de $100 \mu \mathrm{M}$ et la production d'IL-8 induite par l'EBS à des concentrations de plus de $500 \mu$ M. II n'y a pas eu de différence significative entre les effets suppresseurs de la $S(+)$-kétamine et de la R(-)-kétamine sur la production de cytokine pro-inflammatoire induite pas l'EBS.

Conclusion : Cette étude démontre que les isomères de kétamine suppriment la production du FNT-a, d'IL-6 et d'LL-8, induits par l'EBS, dans le sang complet humain.

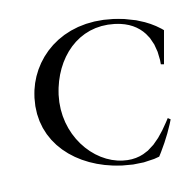

YTOKINES play an important role in the defense against infection; however, excessive production of cytokines is associated with the development of septic shock and organ dysfunction.

Recently, the prevalence of Gram-positive bacterial pathogens as a cause of sepsis has been increasing rela-

From the Department of Anesthesiology, University of Occupational and Environmental Health, Kitakyushu, Japan.

Address correspondence to: Dr. Masanori Ogata, Department of Anesthesiology, University of Occupational and Environmental Health, 1-1-1 Iseigaoka Yahatanishiku Kitakyushu, 807-8555, Japan. Phone: +81-93-691-7265; Fax: +81-93-601-2910; E-mail: mogata@med.uoeh-u.ac.jp

This work was supported, in part, by Grant-in-Aid for Scientific Research 10671453, 12770850 from the Ministry of Education, Science, Sport, and Culture of Japan.

Accepted for publication February 27, 2001.

Revision accepted May 23, 2001. 
tively to Gram-negative pathogens. The mortality of sepsis from Gram-positive pathogens is higher than that from Gram-negative pathogens. ${ }^{1-3}$ Enterotoxins produced by Gram-positive bacilli are potent mitogens for human $\mathrm{T}$ cells, monocytes, and macrophages and cause lethal toxic shock. ${ }^{4}$ Staphylococcal enterotoxins (SEs) and toxic shock syndrome toxin 1 (TSST-1) are wellknown enterotoxins produced by Gram-positive bacilli. These toxins function as superantigens that activate $\mathrm{T}$ cells, monocytes, and macrophages by cross-linking an outside domain of the major histocompatibility complex class II molecules on antigen-presenting cells with the variable portion of the $B$-chain of the $T$ cell receptor, without the internalization and proteolysis required by conventional antigens. ${ }^{5}$ The superantigen activity of SEs results in the synthesis of a variety of cytokines, including interleukin (IL)-1, IL-2, IL-6, IL-8, interferon (IFN)-, and tumour necrosis factor (TNF)-. 6 The massive production and release of such cytokines initiate tissue injury which can cause organ dysfunction and eventually lead to death.

Ketamine, an iv anesthetic, has been advocated for anesthesia of septic or severely ill patients because of its cardiovascular stimulating effects. ${ }^{7,8}$ Ketamine increases cardiac output and systemic vascular resistance, which is thought to stimulate the sympathetic nervous system, resulting in the release of catecholamines. ${ }^{9}$ We previously reported that ketamine suppressed lipopolysaccharide (LPS)-induced TNFproduction in vivo and in vitro. ${ }^{10-12}$ However, there are no reports on the effect of ketamine on SEinduced proinflammatory cytokine production in human whole blood.

In this study, we investigated the effects of ketamine isomers on staphylococcal enterotoxin B (SEB)induced TNF-, IL-6, and IL-8 production in human whole blood in vitro.

\section{Materials and methods}

SEB was purchased from Sigma Chemical (lot. no.86H4062; St. Louis MO, USA). S(+)-ketamine and $\mathrm{R}(-)$ - ketamine were provided by Park-Davis GmbH (Freiburg, Germany).

After approval from our Human Investigations Committee, informed consent was obtained from ten healthy male volunteers not taking any medication. Blood samples were drawn into tubes containing heparin and diluted with five volumes of RPMI 1640 (Nissui Pharmaceutical, Tokyo, Japan). ${ }^{13}$ One millilitre of diluted blood per well was placed into 24-well tissue culture plates (Becton Dickinson, Lincoln Park NJ, USA).

After different doses $(0-1000 \mu \mathrm{M})$ of $\mathrm{S}(+)$-ketamine or $\mathrm{R}(-)$-ketamine were added to each well, whole blood was stimulated with SEB $\left(10 \mathrm{ng} \cdot \mathrm{mL}^{-1}\right)$. Then, the blood was incubated for six hours at $37^{\circ} \mathrm{C}$ in a $95 \%$ air / $5 \% \mathrm{CO}_{2}$ incubator. After incubation, the blood was centrifuged at $700 \mathrm{G}$ for ten minutes to remove blood cells. Supernatant samples were collected and stored at $-80^{\circ} \mathrm{C}$ until assayed.

The L929 cell cytotoxic assay described previously was used to determine the plasma TNF- activity. ${ }^{14}$ Briefly, L929 cells in RPMI 1640 medium containing $5 \%$ fetal calf serum (FCS) were seeded at $3 \times 10^{5}$ cells/well in 96-well flat-bottomed microtiter plates (Becton Dickinson, Lincoln Park NJ, USA) and incubated overnight at $37^{\circ} \mathrm{C}$ in an atmosphere of $5 \% \mathrm{CO}_{2}$ in air. Serial 1:2 dilutions of samples were made in the just-described medium containing $1 \mathrm{mg} \cdot \mathrm{mL}^{-1}$ actinomycin D (Banyu Pharmaceutical Co., Tokyo, Japan), and $0.1 \mathrm{~mL}$ of each dilution was added to different wells. The following day, the cell survival rate was assessed by fixing and staining the cells with crystal violet $(0.2 \%$ in $20 \%$ methanol), and $1 \%$ sodium dodecyl sulfate was added to each well to solubilize the stained cells. The absorbance of each well was determined at $490 \mathrm{~nm}$, using a microplate reader (Bio-Rad Laboratories, Richmond CA, USA). TNF activity was expressed in units per millilitre, which is the reciprocal of the dilution necessary for $50 \%$ lysis of the cells.

The plasma IL-6 concentration was measured in duplicate using a commercially available enzyme-linked immunoassay (IL-6 Enzyme Immunoassay Kit, Advanced Magnetics, Inc., Cambridge MA, USA). The intra- and inter-assay precision was $9 \%$ and $6 \%$, respectively, at an IL- 6 concentration of $88 \mathrm{pg} \cdot \mathrm{mL}^{-1}$. The plasma IL-8 concentration was measured in duplicate using an enzyme-linked immunoassay (IL-8 Enzyme Immunoassay Kit, Advanced Magnetics, Inc., Cambridge MA, USA). The intra- and inter-assay precision was $7 \%$ and $4 \%$ at an IL- 8 concentration of 76 $\mathrm{pg} \cdot \mathrm{mL}^{-1}$. According to the manufacturer, cross-reactivity with other cytokines is negligible in both assays.

To assess the effect of ketamine on leukocyte viability, different doses (0-1000 $\mathrm{uM})$ of $\mathrm{S}(+)$ - or $\mathrm{R}(-)$-ketamine were added to diluted human whole blood and incubated for five hours at $37^{\circ} \mathrm{C}$ in a $95 \%$ air $/ 5 \% \mathrm{CO}_{2}$ incubator. After incubation, the blood was centrifuged at $700 \mathrm{G}$ for ten minutes. Buffy coats were isolated and $\mathrm{NH}_{4} \mathrm{Cl}$ lysis of red blood cells was performed. The white blood cells were resuspended in RPMI 1640 medium containing 5\% FCS and the cells were stained with $0.2 \%$ trypan blue. The cell survival rate was assessed by microscope.

All data are presented as the mean \pm SEM. The paired $t$ test was used for statistical analysis to compare values with the control value. For comparison between 
two groups, one-way repeated-measures analysis of variance was applied. A significant difference was presumed at a probability value of less than 0.05 .

\section{Results}

Human whole blood was stimulated using different doses of SEB $\left(0-100 \mathrm{ng} \cdot \mathrm{mL}^{-1}\right)$. SEB induced TNFproduction in a dose-dependent manner at concentrations between 0.1 and $10 \mathrm{ng} \cdot \mathrm{mL}^{-1}$ in the whole blood. TNF- production reached a plateau with SEB doses of $10 \mathrm{ng} \cdot \mathrm{mL}^{-1}$ or more (Figure 1). Therefore, we used an SEB concentration of $10 \mathrm{ng} \cdot \mathrm{mL}^{-1}$ in our experiments. After adding different doses $(0-1000 \mu \mathrm{M})$ of $\mathrm{S}(+)$ or $\mathrm{R}(-)$-ketamine, whole blood was stimulated with SEB $\left(10 \mathrm{ng} \cdot \mathrm{mL}^{-1}\right)(n=10)$. Figure 2 shows the effects of $S(+)$ - and $\mathrm{R}(-)$-ketamine on SEB-induced TNFproduction. When the blood was incubated for six hours, $50 \mu \mathrm{M} \mathrm{S}(+)$ - and $\mathrm{R}(-)$-ketamine significantly suppressed SEB-induced TNF- production (from $373.3 \pm 89.2$ to $133.3 \pm 39.6 \mathrm{U} \cdot \mathrm{mL}^{-1}$ for $\mathrm{S}(+)$-ketamine and from $426.7 \pm 98.3$ to $123.3 \pm 43.3 \mathrm{U} \cdot \mathrm{mL}^{-1}$ for $\mathrm{R}(-)$-ketamine). $\mathrm{S}(+)$ - and $\mathrm{R}(-)$-ketamine significantly suppressed SEB-induced TNF- production in a dose-dependent manner at concentrations between 50 and $1000 \mu \mathrm{M}$ in comparison with the control $(P$ $<0.05)$. $10 \mu \mathrm{M} \mathrm{S}(+)$ - or $\mathrm{R}(-)$-ketamine had no effect on SEB-induced TNF- production. There were no significant differences between $S(+)$ - and R(-)-ketamine in suppressing SEB-induced TNF- production.

Figure 3 shows the effect of ketamine on SEBinduced IL-6 production. When the blood was incubated for six hours, $100 \mu \mathrm{M} \mathrm{S}(+)$ - and $\mathrm{R}(-)$-ketamine significantly suppressed SEB-induced IL-6 production (from $825 \pm 113.1$ to $579.7 \pm 85.2 \mathrm{pg} \cdot \mathrm{mL}^{-1}$ for $\mathrm{S}(+$ )ketamine and from $991 \pm 109.1$ to $596.3 \pm 94.4$ $\mathrm{pg} \cdot \mathrm{mL}^{-1}$ for $\mathrm{R}(-)$-ketamine). At concentrations between 100 and $500 \mu \mathrm{M}$, SEB-induced IL-6 production was suppressed by $S(+)$ - and $\mathrm{R}(-)$-ketamine in a dose-dependent manner in comparison with the control $(P<0.05)$. 10 and $50 \mu \mathrm{M} \mathrm{S}(+)$ or $\mathrm{R}(-)$ - ketamine had no suppressive effect on SEB-induced IL-6 production. There were no significant differences between $\mathrm{S}(+)$ - and $\mathrm{R}(-)$-ketamine in suppressing SEBinduced IL- 6 production.

The effect of ketamine on SEB-induced IL-8 production is shown in Figure 4. When the blood was incubated for six hours, $500 \mu \mathrm{M} \mathrm{S}(+)$ - and R(-)-ketamine significantly suppressed SEB-induced IL- 8 production (from $1049.2 \pm 47.1$ to $886.6 \pm 31 \mathrm{pg} \cdot \mathrm{mL}^{-1}$ for $\mathrm{S}(+)$-ketamine and from $1033 \pm 37.6$ to $733.7 \pm$ $43.2 \mathrm{pg} \cdot \mathrm{mL}^{-1}$ for $\mathrm{R}(-)$-ketamine $)$. As with TNF- and IL-6 production, $\mathrm{S}(+)$ - and $\mathrm{R}(-)$-ketamine (500-1000 $\mu \mathrm{M})$ also suppressed SEB-induced IL-8 production in

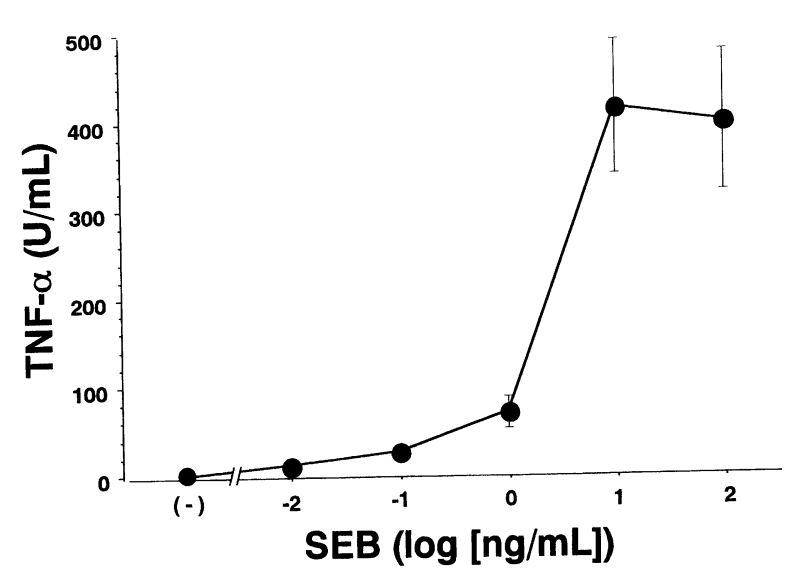

FIGURE 1 Staphylococcal enterotoxin B (SEB)-induced tumour necrosis factor (TNF)- production in human whole blood. Values are expressed as mean $\pm \operatorname{SEM}(n=10)$.

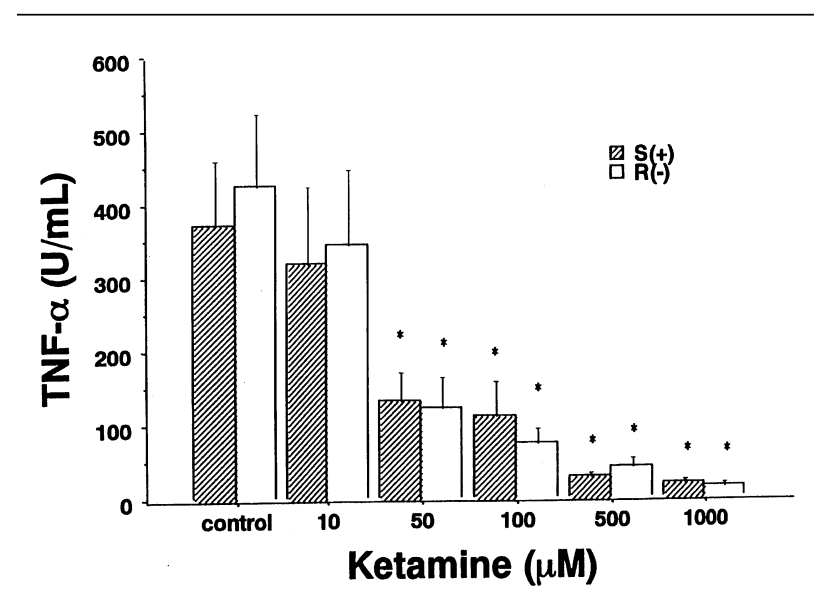

FIGURE 2 Effects of ketamine isomers on staphylococcal enterotoxin B (SEB)-induced tumour necrosis factor (TNF)- production. After ketamine $(0-1000 \mu \mathrm{M})$ was added, human whole blood was stimulated by SEB $\left(10 \mathrm{ng} \cdot \mathrm{mL}^{-1}\right)$ and incubated for six hours. Values are expressed as mean $\pm \operatorname{SEM}(n=10) .{ }^{*} P<0.05$ compared with control.

a dose-dependent manner in comparison with the control $(P<0.05)$. There were no significant differences between $S(+)$ - and $\mathrm{R}(-)$-ketamine in suppressing SEB-induced IL-8 production.

S(+)- and R(-)-ketamine had no effect on L929 cell viability. $S(+)$ - and $R(-)$-ketamine also had no effect on white blood cell viability, as assessed by the exclusion of the vital stain trypan blue (data not shown). 


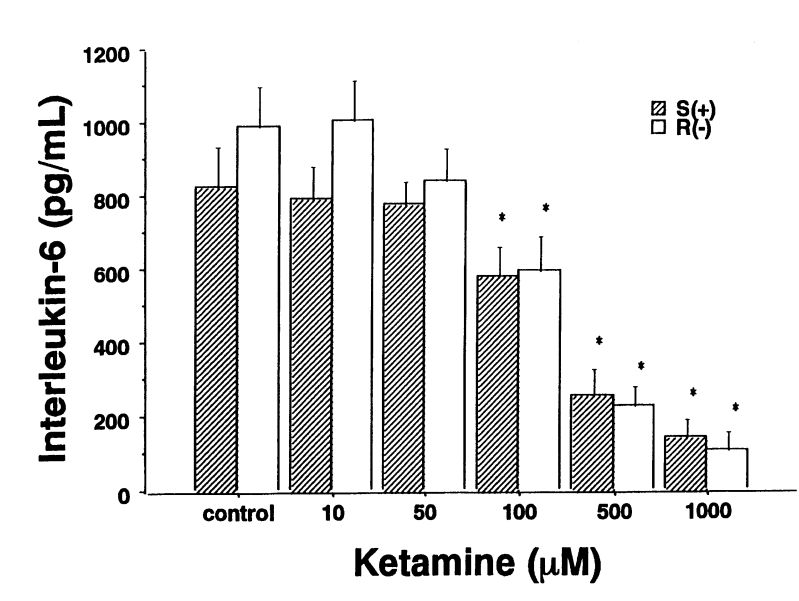

FIGURE 3 Effects of ketamine isomers on staphylococcal enterotoxin B (SEB)-induced interleukin (IL)- 6 production. Afte ketamine $(0-1000 \mu \mathrm{M})$ was added, human whole blood was stim ulated by SEB $\left(10 \mathrm{ng} \cdot \mathrm{mL}^{-1}\right)$ and incubated for six hours. Values are expressed as mean $\pm \operatorname{SEM}(n=10) .{ }^{*} P<0.05$ compared with control.

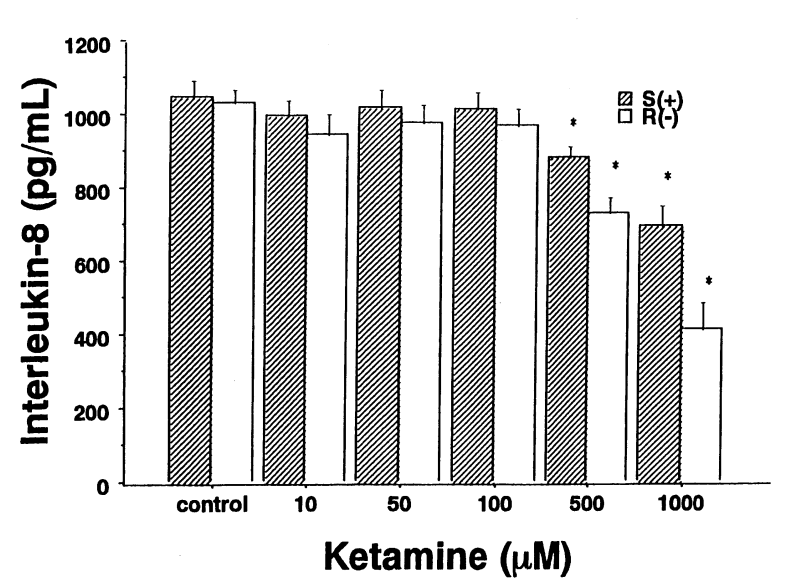

FIGURE 4 Effects of ketamine isomers on staphylococcal enterotoxin B (SEB)-induced interleukin (IL)-8 production. After ketamine $(0-1000 \mu \mathrm{M})$ was added, human whole blood was stim ulated by SEB $\left(10 \mathrm{ng} \cdot \mathrm{mL}^{-1}\right)$ and incubated for six hours. Values are expressed as mean $\pm \operatorname{SEM}(n=10) .{ }^{*} P<0.05$ compared with control.

\section{Discussion}

This study demonstrates that both $\mathrm{S}(+)$ - and R(-)-ketamine suppress SEB-induced TNF-, IL-6, and IL-8 production in human whole blood in vitro.
Since we used human whole blood as an ex vivo model of cytokine production, we could not assess the ability of each cell such as monocytes, macrophages, or $\mathrm{T}$ cells on cytokine production. However, this model reduces the confounding factors that may be associated with the isolation of monocytes or neutrophils. Moreover, whole blood is a more physiologic environment.

The production of TNF-, IL- 6 , and IL- 8 increased significantly in human whole blood when stimulated by SEB (Figures $2-4$ ). It has been reported that superantigens stimulate TNF-, IL- 6 , and IL- 8 production in monocytes, macrophages, and T cells. ${ }^{15-18}$ As shown in Figures 2, 3, and 4, ketamine suppresses SEB-induced proinflammatory cytokine production in human whole blood. Recently, Yan et al. ${ }^{19}$ demonstrated that the cells producing SEB- induced TNF- in human whole blood are mainly $\mathrm{T}$ cells, and not monocytes or macrophages, suggesting that ketamine may suppress the proinflammatory cytokine production of $\mathrm{T}$ cells.

We demonstrated that $50 \mu \mathrm{M}$ and more $\mathrm{S}(+)$ - and $\mathrm{R}(-)$-ketamine suppressed SEB-induced TNF- production and that $100 \mu \mathrm{M}$ and more $\mathrm{S}(+)$ - and $\mathrm{R}(-)$-ketamine suppressed SEB-induced IL-6 production in human whole blood (Figures 2 and 3 ). Furthermore, $500 \mu \mathrm{M}$ and more $S(+)$ - and R(-)-ketamine suppressed SEB-induced IL-8 production (Figure 4). The concentration of ketamine in human plasma reaches $110 \mu \mathrm{M}$ with $i v$ administration of ketamine $2.0-2.2 \mathrm{mg} \cdot \mathrm{kg}^{-1} .^{20}$ This suggests that ketamine might suppress SEBinduced TNF- and IL-6 production at clinical doses.

Ketamine is a racemic mixture $(1: 1)$ of two optically active isomers. Ketamine isomers inhibit N-methyl-Daspartate receptor channels in a stereoselective manner, and this causes their different psychic and analgesic effects. ${ }^{21} \mathrm{~S}(+)$-ketamine is approximately four times as potent as $\mathrm{R}(-)$-ketamine in its psychomimetic and analgesic effects. ${ }^{22}$ Szekely et al..$^{23}$ demonstrated that neutrophil adherence to the coronary vasculature after ischemia was inhibited by $S(+)$-ketamine, however, $\mathrm{R}(-)$ ketamine had no effect on it. In our study, there were no differences between the suppressive effects of $\mathrm{S}(+)$ and $\mathrm{R}(-)$-ketamine. Recently, Weigand et $a l_{.}{ }^{24}$ reported that there was no significant difference in the extent of inhibition of $\mathrm{N}$-formyl-methionyl-leucyl-phenylalaninestimulated CD-18 up-regulation between S(+)- and R(-)ketamine. These results suggested that this effect of ketamine isomers was not mediated through specific receptor interactions.

In a previous study, we reported that the addition of ketamine two hours after stimulation with LPS effectively suppressed TNF production. ${ }^{10} \mathrm{We}$ assume that ketamine may regulate LPS-induced TNF production 
at a posttranscriptional level. However, the mechanism of the suppressive effect of ketamine on SEB-induced cytokine production in human whole blood still remains unclear. Further studies are needed to elucidate the mechanism of the suppressive effect of ketamine.

In conclusion, we demonstrated that $S(+)$ - and $\mathrm{R}(-$ )-ketamine inhibit the SEB-induced production of proinflammatory cytokines, such as TNF-, IL-6, and IL-8, in human whole blood. The suppressive effect of $\mathrm{S}(+)$ - ketamine equaled that of $\mathrm{R}(-)$-ketamine.

\section{References}

1 Leibovici L, Samra Z, Konigsberger H, Drucker M, Ashkenazi S, Pitlik SD. Long-term survival following bacteremia or fungemia. JAMA 1995; 274: 807-12.

2 Bates DW, Pruess KE, Lee TH. How bad are bacteremia and sepsis? Outcomes in a cohort with suspected bacteremia. Arch Intern Med 1995; 155: 593-8.

3 Geerdes HF, Ziegler D, Lode H, et al. Septicemia in 980 patients at a university hospital in Berlin: prospective studies during 4 selected years between 1979 and 1989. Clin Infect Dis 1992; 15: 991-1002.

4 Marrack P, Kappler J. The staphylococcal enterotoxins and their relatives. Science 1990; 248: 705-11.

5 Kappler J, Kotzin B, Herron L, et al. VB-specific stimulation of human $\mathrm{T}$ cells by staphylococcal toxins. Science 1989; 244: 811-3.

6 Kotb M. Bacterial pyrogenic exotoxins as superantigens. Clin Microbiol Rev 1995; 8: 411-26.

7 Lippmann M, Appel PL, Mok MS, Shoemaker WC. Sequential cardiorespiratory patterns of anesthetic induction with ketamine in critically ill patients. Crit Care Med 1983; 11: 730-4.

8 Yli-Hankala A, Kirvelä M, Randell T, Lindgren L. Ketamine anaesthesia in a patient with septic shock. Acta Anaesthesiol Scand 1992; 36: 483-5.

9 White PF, Way WL, Trevor AJ. Ketamine - its pharmacology and therapeutic uses. Anesthesiology 1982; 56: 119-36.

10 Takenaka I, Ogata M, Koga K, Matsumoto T, Shigematsu A. Ketamine suppresses endotoxin-induced tumor necrosis factor alpha production in mice. Anesthesiology 1994; 80: 402-8.

11 Koga K, Ogata M, Takenaka I, Matsumoto T, Shigematsu A. Ketamine suppresses tumor necrosis fac tor- activity and mortality in carrageenan-sensitized endotoxin shock model. Circ Shock 1995; 44: 160-8.

12 Kawasaki T, Ogata M, Kawasaki C, Ogata J, Inoue $\Upsilon$, Shigematsu A. Ketamine suppresses proinflammatory cytokine production in human whole blood in vitro. Anesth Analg 1999; 89: 665-9.

13 Ogata M, Fletcher MF, Kloczewiak M, et al. Effect of anticoagulants on binding and neutralization of lipopolysaccharide by the peptide immunoglobulin conjugate CAPl 8 106 - 138 -immunoglobulin G in whole blood. Infect Immun 1997; 65: 2160-7.

14 Ruff MR, Gifford GE. Purification and physio-chemical characterization of rabbit tumor necrosis factor. J Immunol 1980; 125: 1671-7.

15 Akatsuka H, Imanishi K, Inada K, Yamashita $H$, Hoshida M, Uchiyama T. Production of tumor necrosis factors by human $\mathrm{T}$ cells stimulated by a superantigen, toxic shock syndrome toxin-1. Clin Exp Immunol 1994; 96: 422-6.

16 Bergdoll MS. Enterotoxins. In: Ajl SJ, Monte TC, Kadis S (Eds.) Microbial Toxins. New York: Academic Press, 1970: 265-326.

17 Matsuyama S, Koide $\Upsilon$, Yoshida TO. HLA class II molecule-mediated signal transduction mechanism responsible for the expression of interleukin- $1 \beta$ and tumor necrosis factor- genes induced by a staphylococcal superantigen. Eur J Immunol 1993; 23: 3194-202.

18 Cauwels A, Wan E, Leismann M, Tuomanen E. Coexistence of CD-14-dependent and independent pathways for stimulation of human monocytes by gram-positive bacteria. Infect Immun 1997; 65: 3255-60.

19 Yan Z, Yang DCH, Neill R, Jett M. Production of tumor necrosis factor alpha in human $\mathrm{T}$ lymphocytes by staphylococcal enterotoxin B correlates with toxininduced proliferation and is regulated through protein kinase C. Infect Immun 1999; 67: 6611-8.

20 Domino EF, Zsigmond EK, Domino LE, Domino KE Kothary SP, Domino SE. Plasma levels of ketamine and two of its metabolites in surgical patients using a gas chromatographic mass fragmentographic assay. Anesth Analg 1982; 61: 87-92.

21 Klepstad P, Maurset A, Moberg ER, Øye I. Evidence of a role for NMDA receptors in pain perception. Eur J Pharmacol 1990; 187: 513-8.

22 Hustveit $O$, Maurset $A$, Øye I. Interaction of the chiral forms of ketamine with opioid, phencyclidine, and muscarinic receptors. Pharmacol Toxicol 1995; 77: 355-9.

23 Szekely A, Heindl B, Zabler S, Conzen PF, Becker BF. $\mathrm{S}(+)$-ketamine, but not $\mathrm{R}(-)$-ketamine, reduces postischemic adherence of neutrophils in the coronary system of isolated guinea pig hearts. Anesth Analg 1999; 88: 1017-24.

24 Weigand MA, Schmidt H, Zhao Q Plaschke K, Martin E, Bardenheuer HJ. Ketamine modulates the stimulated adhesion molecule expression on human neutrophils in vitro. Anesth Analg 2000; 90: 206-12. 